\title{
The Potential of Pilixeppus Petersi as a Biocontrol Agent on Musca Domestica
}

\author{
Jesikha. M, \\ PG and Research Department of Zoology, Kongunadu Arts and Science College, Coimbatore 29, Tamilnadu.
}

\begin{abstract}
Chemical insecticides produce the risk of developing pest resistance, side effects to non-target species, and long lived residues in the environment. Generalist Predators can be effective agents of bio-control against Musca domestica L. (house fly). Spiders, particularly assemblages of species, have been shown to be effective in reducing pest insects. Common house fly catcher (Plexippus petersi) is hunting its favorite prey house fly and other small insects. We investigated the potential of jumping spider species to reduce pests in a laboratory setting. In 24, 48 and 32hrs experiment, the mortality rate was increased and finally it reached 100\% mortality rate. Plexippus petersi spiders significantly increased house fly mortality.
\end{abstract}

Key words: House fly, Spiders, Pest, Predators, Mortality.

\section{Introduction}

House fly, Musca domestica $L$. is found in all countries of the world but is more adaptable in warm areas. It is considered one of the most important pests which cause health problems in the environment as it accompanies humans during their daily activity everywhere, both indoors and outdoors, on work sites or in rest places causing much disturbance to them (1). Flies interfere with work such as feeding and milking as well as house flies increased frequency of animal disease transmission, leading to increased medication veterinary service costs, and increased potential for spread of human diseases. It is an important mechanical vector of several bacterial and pathogenic organisms of human and animals (2).

Chemical insecticides are commonly used for their control. Nevertheless, the widespread and inappropriate application of chemical insecticides produce the risk of developing pest resistance, side effects to non-target species, and long lived residues in the environment (3). For this reason, there is a constant search for new alternative control tools (4). Generalist predators can be effective agents of biocontrol (5). Spiders are the major predator in many natural systems.

The paper deals with the potential of Plexippus petersi on Musca domestica L, which is a serious pest for the animal and human health.

\section{Materials And Methods}

Spiders were collected from old fields. Before the experiment, we maintained spiders in individual plastic cages $(18 \times 13 \times 11 \mathrm{~cm})$ in the laboratory on a photoperiod of $13: 11(\mathrm{~L}: \mathrm{D}) \mathrm{h}$ at $29^{\circ} \mathrm{C}$. We provided them with approximately early instars house crickets, Acheta domesticus (L.), per week and fed water in test tubes plugged with cotton. The photoperiod was 14:10h (L:D) and there was no supplemental light provided.

100 number of adult Musca domestica introduced into the cage with 10 adult spiders. The replication set were prepared. The number of dead fly removed in every $24 \mathrm{hrs}$ from the cage and the mortality was calculated.

\section{Results And Disscusion}

Jumping spiders significantly increased house fly mortality. In three treatments the $100 \%$ of mortality was observed in $32 \mathrm{hrs}$ duration. The mean mortality was $34 \%$ in $24 \mathrm{hs}$ duration and $69.33 \%$ in $48 \mathrm{hrs}$ duration (Fig no:1). Chad et al. (6) studied the potential of jumping spider on fourlined plant bug, Plexippus petersi, jumping spiders reduced the number of plant bugs. Plants exposed to plant bugs alone were significantly shorter than either control plants or plants exposed to plant bugs and spiders.

Ximena et al. (7) was recorded biocontrol of juvenile of Bavia sexpunctata on mango leaf; On tree trunk, Portia labiata (tree trunk and ground) by spider Plexippus petersi. These results shows Plexippus petersi spiders significantly increased house fly mortality. It is a promising; Plexippus petersi spiders may prove to be a valuable addition to our current arsenal of bio- control agents.

Spiders, particularly assemblages of species, have been shown to be effective in reducing pest insects and crop damage in field crops and orchards (6).

Jumping spiders significantly increased bug mortality and resulted in taller sweet basil plants. A variety of spider species, including a sizeable minority of the Salticidae, specialise at preying on ants $(8 ; 9 ; 10 ; 11$ and 12) 
IV. Figure

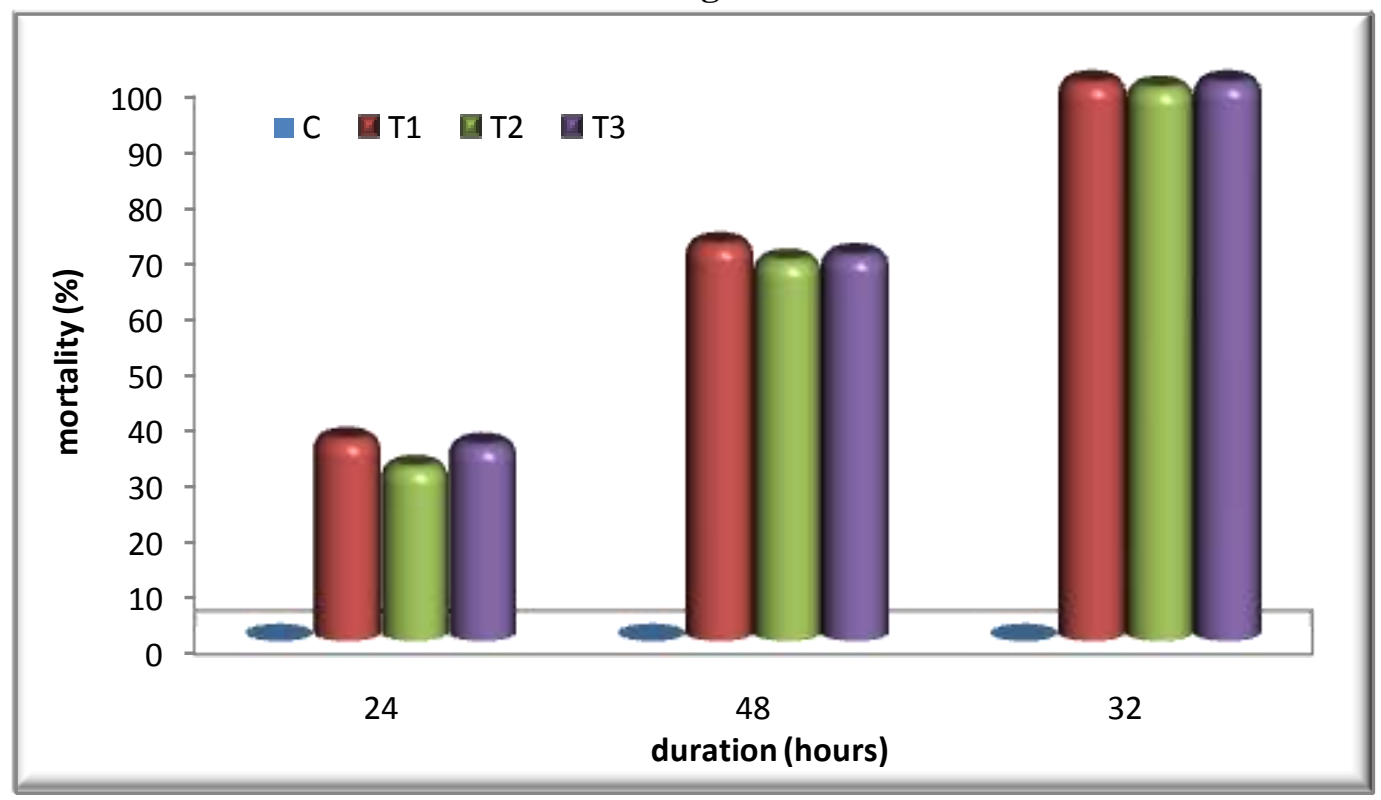

Figure 1: Mortality of Musca Domestica in Plexippus Petersi Treatment

\section{Reference}

[1] A. S. Albarrak, Comparative studies on house fly (Musca domestica), population in different animal farms in relation to attractants and control at hail province, saudi arabia, Pak. Entomol, 31 (2), 2009, 142-148.

[2] D. Chavasse, R. Shler, O. Murphy, S. Hutlly, S. Cousens and T. Akhtar, Impact of house control on childhood diarrhoea in Pakistan: community-randomisedtrial, Lancet. 353, 1999, 22-25.

[3] M. Kristensen and J. B. Jespersen, Larvicide resistance in Musca domestica (Diptera: Muscidae) population in Denmark and establishment of resistant laboratory strains, Journal of Economic Entomology, 96, 2003, 1300-1306.

[4] E. S. Douglass and C. Jesse, Integrated pest management for fly control in Maine dairy farms. Texas Agricultural Extension Service. 4(6), 2002.

[5] W. O. C. Symondson, K. D. Sunderland and M. H. Greenstone, Can generalist predators be effective biocontrol agents? Annu. Rev. Entomol. 47, 2002, 561-594.

[6] D. Chad, Hoefler, Andy Chen and M. Elizabeth Jakob, The Potential of a Jumping Spider, Phidippus clarus, as a Biocontrol Agent. J. Econ. Entomol, 99 (2), 2006, 432-443.

[7] J. Ximena, Nelsona, R. Robert, Jacksona, D. Simon, G. B. Pollardb, Edwardsc, T. Alberto and Barriond, Predation by ants on jumping spiders (Araneae: Salticidae) in the Philippines, Zealand Journal of Zoology, 31 (1), 2010,45 -56.

[8] B. Cutler, Ant predation by Habrocestum pulex (Hentz) (Araneae: Salticidae), Zoologischer Anzeiger, 204, 1980, 97-101.

[9] M. Nyffeler, D. A. Dean and W. L. Sterling, The southern black widow, Lactrodectus mactans (Araneae, Theridiidae) as a predator of the red imported fire ant, Solenopsis invicta (Hymenoptera, Formicidae), in Texas cotton fields, Journal of Applied Entomology, 106, 1988, 52-57.

[10] R. R. Jackson and A. Van Olphen, Prey-capture techniques and prey preferences of Corythalia canosa and Pystira orbiculata, anteating jumping spiders (Araneae, Salticidae), Journal of Zoology London, 223, 1991, 577-591.

[11] R. R. Jackson, and A. Van Olphen, Prey-capture techniques and prey preferences of Chrysilla, Natta and Siler, ant-eating jumping spiders (Araneae, Salticidae) from Kenya and Sri Lanka, Journal of Zoology London, 227, 1992, 163-170.

[12] R. A. Allan, M. A. Elgar and R. J. Capon, Exploitation of an ant chemical alarm signal by the zodariid spider Habronestes bradleyi Walckenaer, Proceedings of the Royal Society of London Series B, Biological Sciences, 263, 1996, 69-73. 